\title{
Spectators on the Run: Factors Affecting Football Attendance in Iranian Football Matches
}

\author{
${ }^{1}$ Kianoosh Shajie, ${ }^{1}$ Mahdi Talebpour*, ${ }^{1}$ Seyed Morteza Azimzadeh, ${ }^{1}$ Mohammad \\ Keshtidar, ${ }^{2}$ Hadi Jabbari Nooghabi
}

${ }^{1}$ Department of Sport Management, Faculty of Sport Science, Ferdowsi University, Mashhad, Iran. ${ }^{2}$

Department of Statistics, Faculty of Mathematics, Ferdowsi University, Mashhad, Iran.

Submitted 02 February 2019; Accepted in final form 13 March 2019.

\begin{abstract}
Background. Sport spectators are an essential part of the professional sport landscape. Spectators are important economically, because they generate revenue through ticket and concession sales, and provide ambience for broadcast televisions. Problematically, spectators' attendance is declining in many professional leagues throughout the world. Objectives. The current study aimed at identifying factors affecting spectators' attendance in the Iranian Football League. Methods. Initial data were collected using semi-structured interviews with 20 participants, with expertise in the Iranian Football League. Using Q Methodology, 50 Q-expressions were sorted by the participants. Then, Q-factor analysis was performed. Results. The study identified seven broad factors: 1) Lack of desirable access and transportation services to/from the stadiums; 2) Defective implementation of strategic plans in federations and clubs; 3) The impact of low-quality plays and the superiority of TV services to stadium ones; 4) Inappropriate services in stadiums; 5) Inappropriate stadium atmosphere; 6) Economic problems of spectators; and, 7) Paying more attention to margins by media from the viewpoint of critics. Conclusions. Football officials can increase the number of spectators in stadiums by systematically removing these damages from the Iranian football body, which may solve many other problems as well.
\end{abstract}

\section{KEY WORDS: Spectator, Mental Model, Declining Presence, $Q$ Methodology}

\section{INTRODUCTION}

The sports marketing industry has changed a lot in the past 20 years, just like companies, organizations, and sports clubs that use new promotional tools to attract more customers in the current competitive environment. It is of special importance to sport event marketers to attract spectators; through the presence of spectators, sport tourists, fans, credible sponsors, and the media are attracted, brand (event) images are developed, and elite participants attend (1). It is hypothesized that the spectators' attendance in stadiums has a multi-dimensional structure that should be considered by event marketers and sport club managers. Behavioral and emotional factors influence spectators' attendance and, if ignored, they deprive attending stadiums (2). The present research aimed at addressing various aspects of the presence and motivation of football spectators in Iranian Football League stadiums and reporting the reasons for their absence from football stadiums using a mental model.

Sports and Watching Athletic Contests. Sports is one of the most important and diverse activities for the leisure of the general public (3).

*. Corresponding Author:

Mahdi Talebpour, Associate Professor

E-mail: mtalebpour@um.ac.ir 
Interest in sports is growing and people now spend more time on sports and leisure activities. The addition of leisure-time activities to people's lifestyles, improved the sports industry and led to growth in sport-related industries such as social health (4). One of the sport-related activities is watching sporting events. This is evidenced by the attendance of spectators at sporting events comprising of various layers of society- i e, old and young men and women with different races and ethnicities. For example, in the 2017-18 season, Manchester United owed about $31 \%$ of its total revenue to ticket sales and supporter membership. Spectators play one of the most important roles in sports leagues and competitions. Sports organizations and clubs should continually try to maintain and increase the number of their spectators. When spectators are eager to watch a sporting event, they are more likely to attend other competitions. The presence of spectators in the stadiums leads to direct and indirect revenues for the club and directly affects the technical performance and results of the team (5). Thus, the revenue from ticket sales and membership fees, purchase of club supplies and equipment, market penetration, and positive effect of spectators attendance in stadiums are the things that clubs do not overlook (5). For this purpose, identifying factors influencing the attendance of spectators in stadiums is of great importance. Providing suitable space for spectators, easy access and appropriate services are important factors mentioned by the researchers (6). According to researchers, playing football is effective as a final product of this sport, while spectators attending. If the quality of game is not approved in a long run by spectators, they undoubtedly avoid attending the stadiums (7-9). Another important factor in the attendance of spectators is the interest in famous players and coaches. Attracting famous coaches and players by clubs is a successful strategy in spectators' attendance (10). Some studies report the two most effective factors in spectators' attendance in various stadiums as physical features and the quality of play.

The Magic of Watching Football. Football is one of the most popular and exciting sports; it has the highest number of athletes and spectators in comparison with other disciplines. Spectators attending stadiums to watch sport competitions are of particular importance to every sport league and are considered as the most important asset for professional clubs, because by buying tickets, they give identity to the leagues and play a great role in the revenue of sports leagues. Spectators' attendance increases the attractiveness of a stadium; even the attractiveness of football in the media is the atmosphere created by the attendance of spectators in the stadiums, which increases the willingness of sponsors to support clubs (11). Spectators go to football stadiums with different motives. Dressing in the colors of a favorite team and shopping for club products are motivations for the spectators (12). Other incentives for spectators to attend football matches are socialization, increased self-confidence, giving identity to a favorite team, communication with favorite players and coaches, entertainment, and the pleasure derived from watching the game (13). Hence, clubs and teams can encourage spectators to attend a stadium to watch matches. According to some studies, spectators go to stadiums to meet needs, gain an experience, or understand the sense of a collective identity, but decline of stadiums attendance reduces the attractiveness of football, and irreparably damages the football body from economic and social aspects. Planning for football, especially European football should target maintaining and increasing spectators' attendance in stadiums. Increasing the quality of services, organizing regular entry and exit points, building attractive shopping and entertainment centers, offering VIP (very important person) seats, and special quality services are the things that do not reduce the number of spectators in European football. Considering the research conducted thus far, one can clearly discern the factors affecting spectators' presence or absence in stadiums.

Ziemnik et al., developed tools to determine factors affecting the attendance at football matches. Environmental factors, facilities, equipment, economic and social factors, entertainment, interest in the game, and the attractiveness of the game were factors affecting spectators' attendance in stadiums, and the validity and reliability of the results were also confirmed (14). Caro et al., studied Spanish Football League and indicated the planning and scheduling of tournaments as the most important factors in spectators' attendance; among these factors, holding games on time, providing easy access to the stadium, and presenting the full schedule of matches early in the season were noteworthy (15). Buraimo, in a unique research 
comparing spectators' attendance in stadiums with television audience, showed that broadcasting television significantly reduces the spectators' attendance in stadiums (16). According to the study by Vallerand, attendance of football fans in stadiums has various causes such as the excitement caused by encouraging a favorite team, participation in small victory celebrations, escaping everyday personal problems, and meeting individual needs (17). Solberg and Turner explored the reasons for the decline in sports attendance in the Norwegian Premier League stadiums. One of the most important results was that the live broadcast of the European Championships on the state television of Norway led to a $68 \%$ decline in attending in Norwegian stadiums (18). In another research, Theodoraski et al., showed that the quality of the match and the services provided in stadiums directly affect the level of desire to attend football matches in stadiums (8). Carvalho et al., identified important factors such as difficult access to the stadiums, a lack of security and relaxation, and the absence of known football stars as well as the high cost of tickets as reasons for declining in spectators' attendance in Belgian and Portuguese stadiums (19). Jere and Matidza studied the factors influencing spectators' attendance at the 2010 South Africa World Cup and identified leisure and watching games with friends, enjoyment of football games, leisure time, fun watching games at home, and security for children at the stadiums as some factors significantly influenced the attendance in stadiums (20). In the same vein, Pomeda et al., analyzed the business model of the Real Madrid Club in a quantitative research. Their findings indicated that the effective management of supporters' emotions was beneficial in increasing the reputation of the team and attracting financial sponsors. Accordingly, the construction of the most architectural well-equipped sport stadiums is planned to satisfy the fans (21). Gonzalez et al., evaluated the reasons for the presence or absence of spectators in great European football leagues and noted type of stadium, the performance and results of teams, weather conditions, the year and the season, and the week day of the game as the most influential factors (22). Recently, Schreyer et al., investigated the determinants of spectators' attendance in football stadiums with a focus on poor behaviors of spectators; their findings clearly indicated a direct relationship between the poor behaviors of spectators and the qualitative aspects of football, such as the performance of the team and the team stars in traditional matches versus rivals (23).

Generally, reduced spectators' attendance in stadiums and vacant spectators' platforms are serious warnings to the organizers of the Iranian Football League as well as club managers. If this condition continues, the football community may observe stadiums free of excitement and football matches with no popular support or capital. Vacant sports platforms, which are referred to as "enduring sports" capitals, had a decreasing trend over the last few years in the Iranian Premier League. During the 2015-16 Premier Football Championships, the average number of spectators was 6500. Under such circumstances, the transforming this discipline into a money-making industry, shifting from traditional to professional conditions, the absence of spectators, and undeniable capital of the Iranian Football League causes irreparable damages to this highly entertaining sport. Therefore, the current study aimed at investigating the decline in attendance and number of sport fans in the stadiums of the Iranian Premier League. Generally speaking, the current research aimed at answering the following questions: What factors reduce spectators' attendance in stadiums to watch football matches? What is the mental model of the decline of spectators in Iranian Football League stadiums?

\section{MATERIALS AND METHODS}

Research methodology. The present mixed methods study applied Q methodology to extract the main factors identified in previous studies and the viewpoint of experts regarding attendance in stadiums. Statistical methods such as Q factor analysis and analysis of main components were used to classify individuals. The main purpose of this method is to reveal different patterns of thinking, rather than just counting the number of people with different thoughts; it is close to the research qualitative method. This method uses subjective opinions to construct a typology of different perspectives. In fact, the $\mathrm{Q}$ methodology is a technique that enables the researcher to identify and classify individuals' perceptions and beliefs and classify groups of people based on their perceptions (24).

Participants. Considering the use of $\mathrm{Q}$ methodology for participant selection, the targeted methods were used with small samples (25). In the present research, five individuals were 
selected out of interviewed Iranian football elites (fans and football spectator) with research background in the relevant field as the study samples. In the field of sorting expressions, an additional 20 participants were selected from coaches active in the Iranian Premier League, elite pioneers and experts, football management experts, sociologists, and media activists in football. A combination of purposeful and nonprobable sampling and snowball sampling was used as the selection method. Participants were selected based on their association with the research subject. Description of the research steps. The research flowchart is summarized in Figure 1.

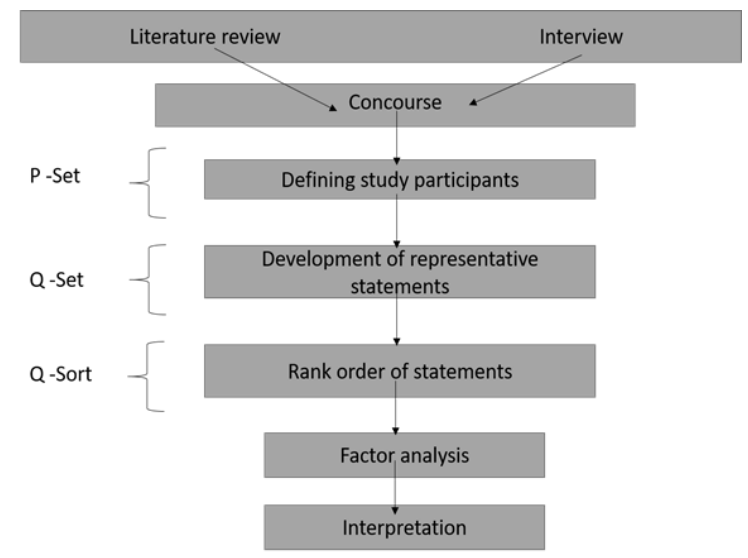

Figure 1. The Study Flowchart

1. Reviewing the literature: In the first step, a library research of scientific articles, books, radio and television debates, newspapers, notes, films, and magazines was conducted, and the reason for declining in spectators' attendance in Iranian football stadiums was identified.

2. Interview: Interviews were used to complete the discourse space. Using targeted and snowball sampling, five people with experience and expertise in this field were interviewed. Participation was voluntary, and participants were assured that their responses would remain confidential. Semi-structured and collaborativeinteractive methods were used for interviewing and collecting data. Each interview lasted 15 to 20 minutes and was recorded. As soon as the interviews were completed, the information was evaluated and finalized.

3. Collection of discourse space: All the information derived from the first and second stages was merged, and accordingly, discourse of the research was created.
4. Evaluation and collection of discourse space: The collected information was converted into short interrupted expressions, and the sample was selected from them. The sample equaled a total of 65 expressions.

5. Finalization of $\mathrm{Q}$ expressions: The 65 selected expressions were related to decline in spectators' attendance at Iranian Premier League matches. After interviewing three sports management experts, similar and repeated expressions were removed and ambiguities were resolved, and 50 expressions were selected as the final ones for the $\mathrm{Q}$ sample in the present research.

6. Selection of participants: With the $\mathrm{Q}$ method, a sample size of 28 was sufficient to achieve different viewpoints. Therefore, sample selection was not possible through probabilistic sampling methods; rather, purposive sampling method was used to provide a small sample size. In the present research, 20 individuals including coaches active in Premier League, pioneers, sports management specialists, sociologists, and members of the sports media were selected.

7. Sorting the Q diagram: Participants were asked to place each of the cards on the diagram according to the sorting instructions. The Q diagram with its normal and compulsory distributions was used. This diagram is designed to sort $50 \mathrm{Q}$ expressions from -5 (the least impact with the expression) to +5 (the highest impact with the desired expression).

8. Q factor analysis: After the Q-sort, Q factor analysis was performed with SPSS version 25 .

Research Tool. Interactive and collaborative interviews were conducted in the qualitative part of the study, and in the quantitative part, the Q diagram was used to transfer information from the qualitative section with normal and compulsory distributions. The validity of the tool, which is relied on the comprehensiveness of the expressions in the $\mathrm{Q}$ method and the $\mathrm{Q}$ diagram, was confirmed by three sports management experts (26). In addition, as soon as the cards were sorted, a feedback was received from the participants, which indicated the selected expressions were suitable to measure the research subject. The reliability of the diagram and the $\mathrm{Q}$ cards was measured using the inter-raters reliability method. Hence, four scorers were asked to complete the diagram. The correlation coefficient of 0.85 indicated the inter-raters 
reliability. Figure 2 shows the study diagram and Q structure.

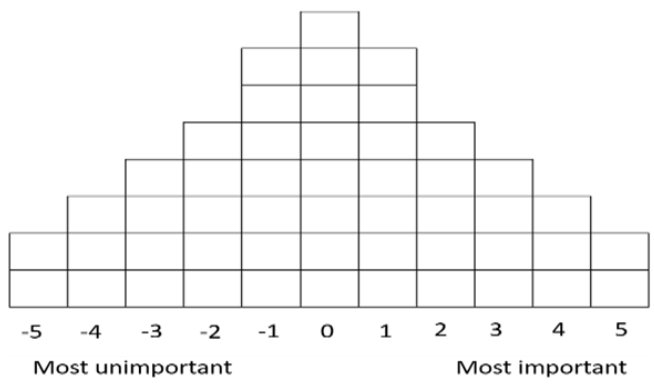

Figure 2. Diagram Structure for Arranging Q

Data Analysis. Initially, data extracted from the interviews were filtered by the researcher, and irrelevant data were eliminated. Next, the data was summarized into short, understandable concepts. Then, the data were finalized, written in $\mathrm{Q}$ expressions on $\mathrm{Q}$ cards, and shared with the participants, who then sorted and scored each expression. The scores were recorded on a designed form and entered into SPSS version 25 to identify the participants' mentalities through factor analysis and to answer the research questions.

Unlike the previous stage in which the qualitative method was used, at this point, Q factor analysis, a quantitative research procedure, was employed to identify similar mentalities among the participants. Factor analysis is the most common statistical method used to analyze the $\mathrm{Q}$ data matrix. The basis of this method is also the correlation between individuals; therefore, Q factor analysis is used to emphasize that in the process of factor analysis the individuals are classified instead of the variables. However, there is no statistically significant difference between Q factor analysis and conventional factor analysis. Therefore, correlation matrix, a conventional method, was used in the current study to perform factor analysis. The factors were orthogonally rotated using the Varimax method. The numbers originated from the $\mathrm{Q}$ factor analysis and were extracted using the main components method.

\section{RESULTS}

Participants' data are summarized in Table 1. Figure 3 shows that, to select the number of suitable factors, the special values greater than 1 were confirmed and selected. Accordingly, seven factors or mental patterns were extracted. Based on the table of variances illustrated in Table 3 , the identified damages can be expressed based on the importance of mental patterns. The obstacles identified in mental model No. 1 were more important than other mental patterns, because they explained $13.08 \%$ of the total variance.

Table 1. Demographic Information of the Study Participants

\begin{tabular}{|c|c|c|c|c|c|c|c|c|c|}
\hline $\begin{array}{l}\text { Participa } \\
\text { nts }\end{array}$ & $\begin{array}{l}\text { Age, } \\
\text { yr }\end{array}$ & $\begin{array}{l}\text { Educati } \\
\text { on } \\
\text { Level }\end{array}$ & $\begin{array}{l}\text { Organizational } \\
\text { Position }\end{array}$ & $\begin{array}{l}\text { Experi } \\
\text { ence, } \\
\text { yr }\end{array}$ & $\begin{array}{l}\text { Partici } \\
\text { pants }\end{array}$ & $\begin{array}{l}\text { Age, } \\
\mathrm{yr}\end{array}$ & $\begin{array}{l}\text { Educati } \\
\text { on } \\
\text { Level }\end{array}$ & Organizational Position & $\begin{array}{l}\text { Experien } \\
\text { ce, } \mathrm{yr}\end{array}$ \\
\hline 1 & 45 & $\mathrm{PhD}$ & Faculty member & 20 & 11 & 45 & $\mathrm{PhD}$ & $\begin{array}{l}\text { Faculty member and } \\
\text { qualified football coach }\end{array}$ & 27 \\
\hline 2 & 35 & MSc & $\begin{array}{l}\text { Former employee of } \\
\text { the Football } \\
\text { Federation }\end{array}$ & 8 & 12 & 53 & $\mathrm{BSc}$ & $\begin{array}{l}\text { Former national team } \\
\text { player }\end{array}$ & 40 \\
\hline 3 & 42 & $\mathrm{PhD}$ & $\begin{array}{l}\text { Faculty member and } \\
\text { qualified football } \\
\text { coach }\end{array}$ & 18 & 13 & 30 & $\mathrm{BSc}$ & $\begin{array}{l}\text { Player of a club in Iranian } \\
\text { Premier League }\end{array}$ & 15 \\
\hline 4 & 51 & $\mathrm{PhD}$ & $\begin{array}{l}\text { Faculty member and } \\
\text { former national team } \\
\text { player }\end{array}$ & 30 & 14 & 33 & MSc & Prominent football coach & 17 \\
\hline 5 & 63 & $\mathrm{PhD}$ & $\begin{array}{l}\text { Faculty member, top } \\
\text { national club player, } \\
\text { and football coach }\end{array}$ & 20 & 15 & 47 & $\mathrm{BSc}$ & $\begin{array}{l}\text { former football player and } \\
\text { football reporter }\end{array}$ & 18 \\
\hline 6 & 56 & $\mathrm{PhD}$ & $\begin{array}{l}\text { Faculty member, } \\
\text { former football player }\end{array}$ & 25 & 16 & 48 & MSc & $\begin{array}{l}\text { former football player and } \\
\text { qualified employee of the } \\
\text { Football Federation }\end{array}$ & 23 \\
\hline 7 & 55 & $\mathrm{PhD}$ & $\begin{array}{l}\text { Faculty member and } \\
\text { former football coach }\end{array}$ & 30 & 17 & 54 & $\mathrm{PhD}$ & $\begin{array}{l}\text { Faculty member and } \\
\text { prominent football coach }\end{array}$ & 38 \\
\hline 8 & 39 & MSc & Football reporter & 15 & 18 & 69 & $\mathrm{PhD}$ & $\begin{array}{l}\text { Faculty member and } \\
\text { former player in Iranian } \\
\text { national team }\end{array}$ & 40 \\
\hline 9 & 42 & $\mathrm{BSc}$ & $\begin{array}{l}\text { Former Iranian } \\
\text { national team player }\end{array}$ & 25 & 19 & 41 & $\mathrm{BSc}$ & $\begin{array}{l}\text { Coach of a club in the } \\
\text { Iranian Premier League }\end{array}$ & 32 \\
\hline 10 & 42 & $\mathrm{BSc}$ & $\begin{array}{l}\text { Coach of a club in } \\
\text { Iranian Premier } \\
\text { League }\end{array}$ & 20 & 20 & 40 & $\mathrm{PhD}$ & $\begin{array}{l}\text { Faculty member and player } \\
\text { of a club in Iranian Premier } \\
\text { League }\end{array}$ & 24 \\
\hline
\end{tabular}


Table 2. Statistics Related to Factor Analysis of Q

\begin{tabular}{|c|c|c|c|c|}
\hline & \multicolumn{2}{|c|}{ Extraction Set of Load Squares } & \multicolumn{2}{|c|}{ Rotational Set of Load Squares } \\
\hline & Assembly Percentage & Total & Variance Percentage & Assembly Percentage \\
\hline 1 & 01.22 & 40.4 & 08.13 & 08.13 \\
\hline 2 & 79.35 & 75.2 & 55.12 & 64.25 \\
\hline 3 & 00.45 & 84.1 & 83.11 & 48.37 \\
\hline 4 & 93.52 & 58.1 & 90.9 & 38.47 \\
\hline 5 & 07.60 & 42.1 & 18.8 & 56.55 \\
\hline 6 & 86.65 & 15.1 & 11.8 & 68.63 \\
\hline 7 & 04.71 & 03.1 & 36.7 & 04.71 \\
\hline
\end{tabular}

As seen in Table 2, participants identified seven factors, which explained and covered about $71.4 \%$ of the variance. Using the scree plot test, the suitable factors were identified and selected. Figure 3 shows the factor status in the two $\mathrm{X}$ and $\mathrm{Y}$ axes. Therefore, the significance of the damages identified in the seven mental patterns was similar to Table 3 . The rotated factor matrix was used to interpret and identify the factors. With the help of this matrix, it was determined which of the expressions has created any of the mental patterns.

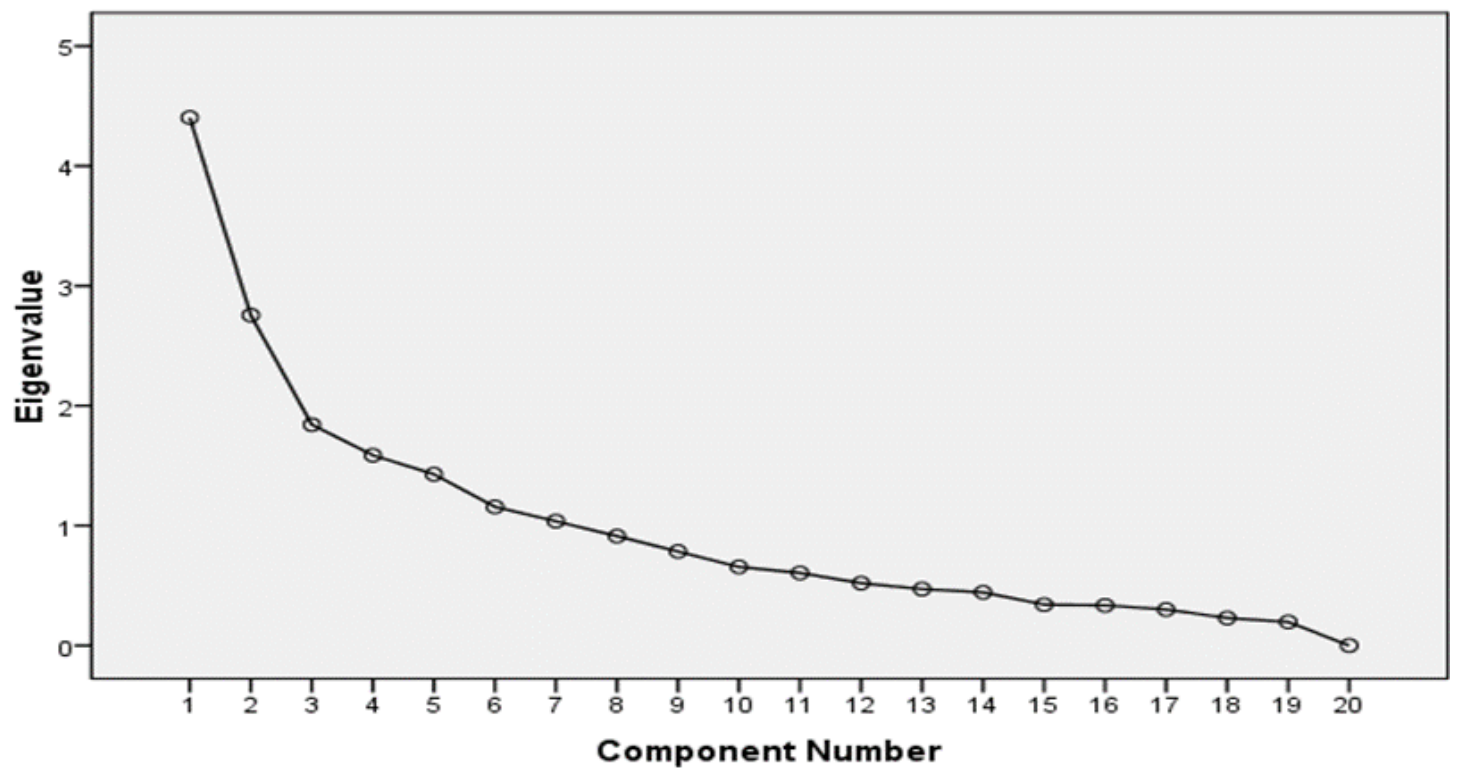

Figure 3. The Cairn diagram of factors in the current study

Table 3. Rotated Factor Matrix for the Current Study

\begin{tabular}{|lccccccc|}
\hline Participant & $\mathbf{1}$ & $\mathbf{2}$ & $\mathbf{3}$ & Mental Pattern & $\mathbf{4}$ & $\mathbf{5}$ & $\mathbf{6}$ \\
P1 & 0.094 & 0.273 & 0.209 & 0.024 & 0.777 & 0.487 & -0.311 \\
P2 & 0.779 & -0.162 & -0.022 & 0.145 & 0.226 & -0.172 & 0.210 \\
P3 & 0.035 & 0.634 & -0.354 & -0.525 & 0.014 & -0.022 & -0.220 \\
P4 & 0.026 & -0.125 & -0.106 & 0.854 & 0.596 & 0.184 & 0.039 \\
P5 & 0.830 & -0.277 & 0.149 & -0.009 & -0.064 & -0.010 & -0.187 \\
P6 & 0.220 & 0.241 & -0.040 & -0.300 & -0.266 & -0.158 & 0.661 \\
P7 & 0.049 & -0.021 & 0.782 & -0.120 & 0.063 & 0.164 & -0.145 \\
P8 & 0.838 & -0.092 & 0.080 & 0.062 & 0.033 & -0.312 & 0.006 \\
P9 & 0.074 & 0.162 & 0.358 & 0.223 & 0.157 & -0.046 & 0.715 \\
P10 & 0.118 & 0.715 & -0.029 & -0.149 & 0.025 & 0.028 & 0.085 \\
P11 & 0.626 & 0.155 & 0.301 & -0.124 & 0.523 & 0.154 & -0.213 \\
P12 & 0.304 & 0.064 & 0.324 & -0.469 & -0.060 & 0.427 & 0.340 \\
P13 & -0.156 & 0.402 & -0.038 & -0.008 & 0.099 & 0.566 & 0.034 \\
P14 & -0.208 & 0.679 & -0.045 & 0.038 & 0.210 & -0.116 & -0.014 \\
P15 & -0.010 & -0.030 & 0.313 & -0.167 & -0.013 & -0.780 & 0.240 \\
P16 & -0.016 & -0.118 & 0.845 & -0.083 & 0.057 & -0.068 & 0.311 \\
P17 & 0.444 & -0.007 & 0.343 & -0.079 & 0.015 & 0.007 & -0.032 \\
P18 & -0.026 & -0.029 & 0.280 & 0.516 & -0.156 & 0.240 & -0.097 \\
P19 & 0.141 & 0.609 & -0.027 & 0.742 & 0.120 & 0.163 & 0.247 \\
P20 & -0.248 & 0.794 & 0.357 & 0.111 & 0.131 & 0.503 & 0.171 \\
\hline
\end{tabular}


Table 4. Prioritizing the Identified Damages Based on the Mental Pattern

\begin{tabular}{|c|c|c|}
\hline Phrase & Agree Proposition & Mental Pattern \\
\hline $\mathbf{P 2 , P 5 , P 8 , P 1 1 , P 1 7 ~}$ & & $\begin{array}{l}\text { In terms of } \\
\text { infrastructure }\end{array}$ \\
\hline Q 1 & Lack of desirable access and transportation services to stadiums & \\
\hline Q 2 & Lack of necessary safety standards in stadiums & \\
\hline Q 3 & Inappropriate design and lack of attention to the aesthetic aspects of stadiums & \\
\hline Q 5 & Lack of adequate security for spectators in stadiums & \\
\hline Q 6 & Inappropriate and disorganized ticketing system & \\
\hline Q 21 & Poor online ticketing system & \\
\hline Q 50 & Lack of home stadiums for clubs & \\
\hline Q 13 & Poor quality of matches and players' performance in the league & \\
\hline Q 14 & Poor technical performance of coaches & \\
\hline $\mathbf{P 3 , P 1 0 , P 1 4 , P 2 0}$ & & In terms of quality \\
\hline Q 19 & Poor performance of the national team in the minds of spectators & \\
\hline Q 24 & Lack of first-rate, authentic, quality stars in the clubs & \\
\hline Q 41 & Analysis and interpretation of Iranian Premier League matches in audiovisual media & \\
\hline Q 45 & Live broadcasting of global football events & \\
\hline Q 9 & $\begin{array}{c}\text { Lack of planning on training, recruitment, and organization of fans by the Football } \\
\text { Federation }\end{array}$ & \\
\hline Q 17 & State owned clubs or lack of planning and tendency towards private sector management & \\
\hline Q 18 & Lack of strategic planning to attract fans to stadiums by the Federation & \\
\hline Q 22 & Lack of proper planning for the fan engagement leadership by clubs & \\
\hline Q 23 & Lack of proper planning on customer relations, unified marketing, and branding by clubs & \\
\hline P7,P15,P16 & & In terms of strategy \\
\hline Q 25 & Negative behavior of spectators in stadium & \\
\hline Q 26 & No plan or strategy to assign television broadcasting rights to clubs & \\
\hline Q 27 & Instability in club management & \\
\hline Q 28 & Lack of proper planning for the league organization (calendar, day, hour, etc.) & \\
\hline Q 30 & Poor performance of club managers & \\
\hline Q 34 & Inability to plan, train, organize, and generally manage leaders by clubs & \\
\hline Q 46 & Lack of correct planning and communicational marketing by clubs & \\
\hline Q 4 & Superior quality of TV streaming services to stadium services & \\
\hline P18, P19 & & In terms of services \\
\hline Q 31 & Lack of amenities and proper services in the stadiums for spectators & \\
\hline Q 36 & Lack of amenities, commercial, and tourist services around the stadiums & \\
\hline Q 7 & Inappropriate atmosphere of the stadium for children and women & \\
\hline Q 8 & Inappropriate and anti-social behaviors of players, coaches, and managers & \\
\hline Q 10 & Informal communications among leaders, players, and coaches & \\
\hline Q 11 & Excessive tendency of players toward drugs & \\
\hline P1,P4 & & In terms of morality \\
\hline Q 37 & Lack of bias and commitment to clubs by players & \\
\hline Q 38 & Lack of bias to clubs by coaches and the changing clubs per season & \\
\hline Q 39 & Inconsistency of morality and behaviors with social norms in players, coaches, and managers & \\
\hline Q 40 & Excessive violence in football matches and its transfer from the ground to the platform & \\
\hline Q 42 & Tendency of leaders toward the margins and their inappropriate wording & \\
\hline Q 43 & Spectators' inappropriate wording in stadiums & \\
\hline Q 44 & Excessive tendency of coaches toward drugs & \\
\hline Q 47 & Spectators' aggression during matches & \\
\hline Q 48 & Inappropriate behavior of security forces and organizers of tournaments & \\
\hline Q 49 & Immoral guidance of leaders and sports incentives & \\
\hline P12,P13 & & In terms of economy \\
\hline Q 20 & Economic difficulties of spectators & \\
\hline Q 32 & Expensive and disorganized ticketing system & \\
\hline Q 12 & Excessive addressing of the margins by media & \\
\hline Q 15 & Failure to produce professional football TV series to attract more spectators by media & \\
\hline $\mathbf{P 6}, \mathbf{P 9}$ & & In terms of media critics \\
\hline Q 16 & The process and type of dealing with football-related issues in football TV series & \\
\hline Q 29 & Failure to develop a strategy to resolve immoralities in stadiums by media & \\
\hline Q 32 & Poor encouragement to attend stadiums as a cultural duty by media & \\
\hline Q 35 & $\begin{array}{l}\text { Inclination towards the Internet and the pursuit of football through the media and social } \\
\text { networks }\end{array}$ & \\
\hline
\end{tabular}

As shown in Table 3, the rotated factor matrix was used to determine which damage occurs in which mental pattern. The largest positive number for each mental pattern indicates the location of the damage in that pattern as well. Table 4 shows the final result of mental patterns.Based on the results, seven distinct mental patterns regarding the absence of spectators from the stadiums to watch Iranian Football league matches were identified. In which mental pattern each of the 20 participants was placed was previously clarified. Figure 4 illustrates the mental pattern of experts in respect to reduced spectators' attendance in stadiums. 


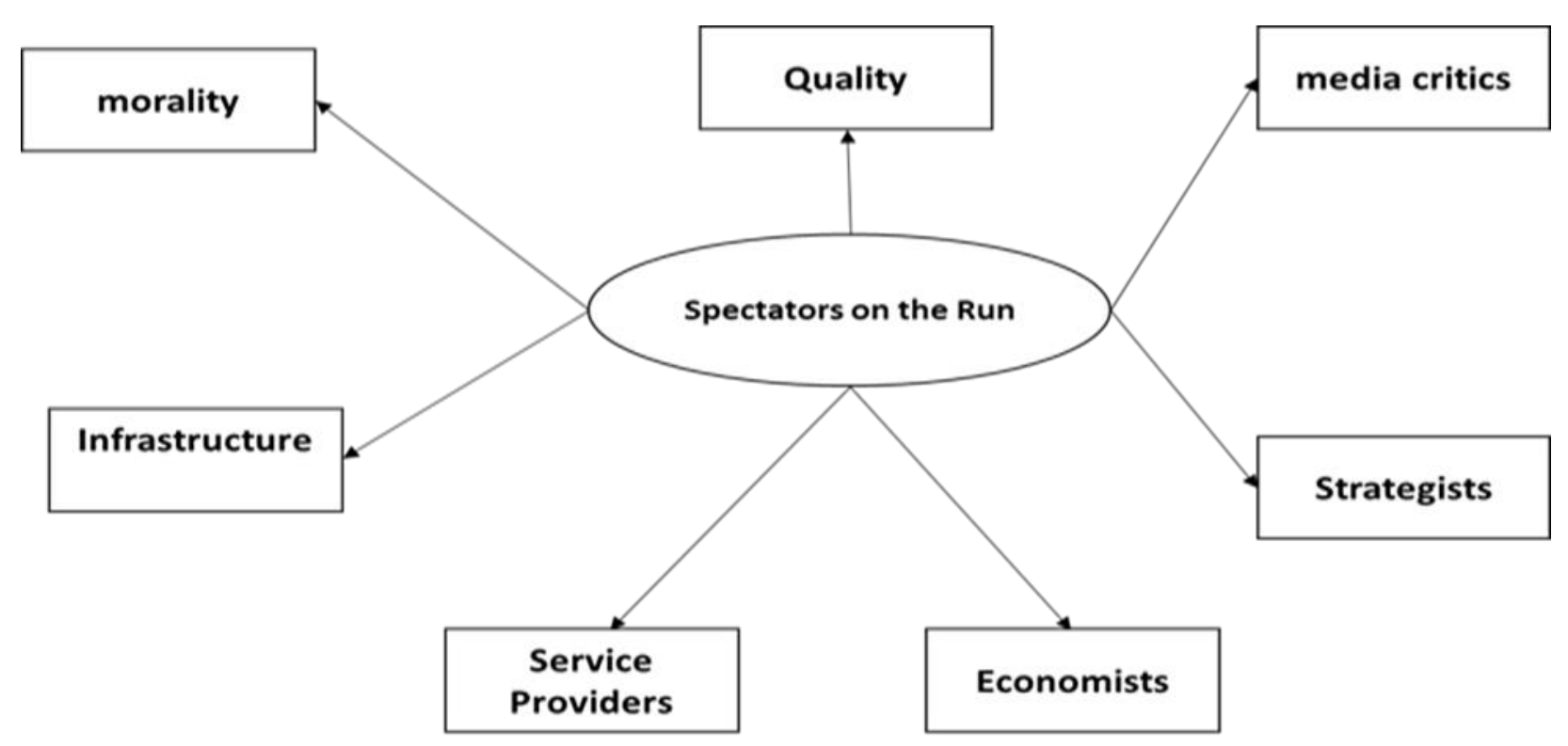

Figure 4. Mental Model of Reduced Attendance in Stadiums to Watch Iranian Football League Matches

The mental model of Iranian football experts shown in Figure 4 regarding reduced number of spectators in stadiums was according to the study findings. According to Figure 4, the greatest number of $\mathrm{Q}$ was correlated with the mental pattern of morality ranked 5th in terms of importance.

Infrastructures. Based on the mentality and viewpoint of the study participants, the lack of amenities in stadiums, security, attention to aesthetic issues, and most importantly, the lack of desirable access and transportation services to/from stadiums were among the reasons for spectators' absence from stadiums. In other words, this group of experts believed that approaching hardware standards in stadiums can increase football events attendance in stadiums. A proper infrastructure for online ticketing allows the spectators to effortlessly and safely purchase tickets without spending several hours on a line; a basic issue noted in this mental pattern. The design and construction of high-security stadiums is another key point that fells into this mental pattern.

Quality. Based on this mental pattern, everything in a football match with the maximum attendance in the stadiums depends on the quality of the match. The inadequate performance of players, coaches, referees, and all individuals involved in a football match can reduce attendance in stadiums. The presence of the firstrate players, native and foreign world-class coaches were other factors influencing attendance mentioned in this mental pattern.

Strategists. This mental pattern clearly showed that the damages to Iran's football are due to the lack of strategic planning in the football body. The lack of planning for attracting and retaining spectators and the lack of communication marketing to increase attendance were the reasons for the creation of this mental pattern. Strategic and long-term planning to attract and retain spectators and fans as a priority of the Iran's Football Federation, clubs, and football organizations was proposed in this mental pattern.

Service Providers. Proponents of this mental pattern believed that the poor quality of services provided in football stadiums and the better quality of the video media (TV) declined attendance of spectators. Moreover, the lack of commercial and tourism services around stadiums, which currently is considered as the most important and profitable option of a football match is another reason for the decline in spectators' attendance in stadiums. Suitable seats, proper play position, scoreboard position, stadium speaker notification, safe and inexpensive drinks and foods, and convenient access to transportation system after the match were some of the other important issues proposed in this mental pattern.

Morality in Football. Experts in this mental pattern considered morality as a priority. 
According to them, the atmosphere of stadiums is far from ethical issues and norms, which results in less inclination to attend stadiums. The desired atmosphere of the stadium for younger fans and the ethical concerns of players and coaches in order to relax the platforms were some of the most important issues of attendance in stadiums mentioned in this mental pattern. The proper attitude of officials and security guards, proper management of teams by coaches, and observing morality by players were other important ethical subjects.

Economists. Based on this mental pattern, the economic status of spectators and fans of the Iranian Premier League clubs had a direct correlation with attendance rate in stadiums. A fan that has no economic and social priorities also has no interest to attend football matches in a stadium. Expensive tickets, expensive transportation (especially for stadiums located in suburban areas), and expensive stadium services are among the factors mentioned in this mental pattern.

Media Critics. The experts in this mental pattern called to mind the inevitable impact of sports media on declining in spectators' attendance in the Iran's stadiums. The media, which can play an important role in changing people's attitudes towards football and, consequently, persuading them to attend stadiums, has serious pitfalls in this regard. The failure to produce professional football TV series, inappropriate use of some visual and written media, and paying excessive attention to football margins may be other reasons for the development of this mental pattern.

\section{DISCUSSION}

Based on the results, the main obstacles to increase spectators' attendance were prioritized according to the seven mental patterns. Subsequently, these mental patterns were discussed and analyzed. Considering the results and the first mental models, raising the technical quality and paying more attention to aesthetics aspect of stadiums are the points that need to be addressed more than ever. Just having a lot of space in the stadiums is not an appeal to spectators. The researchers believed that a good environment and architectural design can affect attendance in stadiums, which leads to club loyalty (1). Ease of access, an easy-to-use online ticketing system, parking, and shopping and amenity centers were the advantages that can affect attending stadiums, and lack of paying attention to these factors can ban spectators' attendance (6). According to research, strategic planning in football focuses on the construction of home stadiums that is a key factor in the development of professional football leagues and improves spectators' attendance. Innovation and creativity were important in the construction of home stadiums (27). In the digital era and small global village where everything can be detected and tracked, people compare their demands with global standards and do not easily satisfy; the point that should be considered by sport officials. The exploitation of stadiums with hundreds of seats with no primary study in this regard and ignoring important issues in the construction of sport spaces do not resolve Iran's football issues and cannot recall the spectators to stadiums.

A functional suggestion to increase attendance can be the improvement of amenity services in stadiums. Providing shopping and entertainment centers around the stadiums can also have a positive effect on the tendency of people toward attending matches. Suitable ticket prices and launching an online ticketing system are also helpful; tickets and seats sold to spectators are not available and not to be used by anyone else. Iran Football Federation officials should also consider the physical space in stadiums and monitor selling VIP seats throughout the season for loyal club fans, which can influence the satisfaction of fans and spectators. This finding was consistent with the results of Greenwell et al., Dhurup et al., and Greenwell et al.

Based on the results, the high or poor quality of a football match, which is considered as its ultimate and original product, has a direct impact on the attendance of spectators in the stadium. It should be noted that live broadcasting of world football events by the national media gives spectators the opportunity to compare the quality of Iranian football matches with those of the world's top leagues. Accordingly, a basic plan should be provided to improve the quality of football in Iran. Strengthen the official team of clubs, train football talents in young-age groups and subsequently recruit them into the Iranian Football League, provide requisites for first-class players in the Premier League, and attract worldclass coaches with international experience by clubs are other factors that can affect the quality of Iranian football in the future. Players in all the 
matches try to improve the attractiveness of the team and inclination of the spectators to support it. Football is one of the most popular sports worldwide. The story of life, how to deal with society, and the extent of the presence of players in the media are some the things that make a positive image of football players in the mind of spectators and fans (28). However, the most important issue that makes spectators more interested in players is their technical performance on the ground. As the technical performance of players decreases, the attractiveness of that sport also drops off. Worldclass football coaches, pillars of football, can give their fans good memories with their technological strategies and optimal use of resources. Moreover, the recruitment of star players from domestic or overseas clubs can be effective in bringing spectators and football enthusiasts to the stadiums (29). Finding elite talents, training and inducing professionalism in football, training mental skills, using up-to-date skills to improve fitness, and using software for technical analysis and evaluation at the club level are some suggestions that can be made to fill the gaps. This finding was consistent with those of Zhang (30).

According to the findings of the current research, strategic and long-term planning as well as microscale operational planning is among the determinants of increased attendance. Since many years ago, no success is achieved in football; hence, a program should be planned in the thought rooms. To attract more people to stadiums, event marketers can extract the motivators of spectators in terms of the culture and existing challenges and focus specifically on advertising and marketing for the presence of people in stadiums. The Iranian Football Federation can take a major step in writing a strategic document to attract spectators and fans to the stadiums. Solving the challenge of women's attendance in stadiums is the point that can be effective. Clubs, effective factors in attending football matches, can solve a large number of problems by using strategic models for marketing communications. Strategists also blame clubs and their poor strategies to overcome this dilemma in Iran's football. Accordingly, providing a powerful information system, planning on reciprocal and long-term communication with the spectators, and promoting people to attend football matches orally and practically lead to spectators' loyalty and attendance in stadiums, which should be placed on the clubs' agendas (31). League organization as the management of the tournaments is one of the most important factors in recalling and reconciliation of spectators that avoids attendance in stadiums. Planning the proper time and space for the tournaments and creating the appropriate atmosphere to increase attendance are useful measures. This finding is consistent with that of Donihue et al. (7).

Based on the viewpoints of the experts, with advancements in social networks the opportunity was provided for spectators to make comparisons; it is not easy to get customers' satisfaction! To this end, the provision of well-deserved customer services is one of the main factors in maintaining satisfaction and attracting spectators to football stadiums (32). Desirable and clean seats, good reception, fun and appealing programs, scoreboard quality, symbols and flags of the favorite team, behavior and appearance of the guides and volunteers in the stadium, and the presence and behavior of security forces are the facilities that, if improved, can promote attendance in stadiums. Furthermore, the use of football experts before and after the match, reviewing the history of games, analyzing and evaluating the technical performance of players and coaches, providing a complete report of the competition by the reporter, and the use of SLAM and repetitive systems in attractive scenes are among the things that make spectators to sit at home and watch the game on TV. Attending stadiums just to socialize with other spectators simply cannot compete with the media services that are increasingly developing. Hence, improving the quality of services in stadiums in order to increase spectators' attendance is a top urgent. Generally speaking, good services in stadiums can include the appropriate quality of the matches, the good performance of the players, the performance and services of the stadium staff, as well as the suitable seats, which should be considered by the relevant authorities (33).

In view of the findings and the mental pattern of moralists, improper and poor ethical practices in stadiums, which can be influenced by factors such as the aggressive behavior of players and coaches, unfair matches, and the socioeconomic problems of spectators may reduce attendance in stadiums (34). Other factors, such as irregularities inside the stadiums, inappropriate services and amenities, referee's biased judgment, provocative 
moves by players and coaches, and population congestion were other causes of violence, which distract spectators, especially the young ones and their families. Identifying people with moral and behavioral problems and preventing their re-entry into football stadiums, public announcement by the national media, strengthening the fan base and holding briefings for fans and spectators are recommended in order to increase spectators' attendance.

Based on the mental pattern of economy, since spectators are struggling with economic difficulties, they may no longer be willing to attend those stadiums that offer the poor services. Moreover, the unreasonable cost of tickets for football matches, spectators' dissatisfaction with the quality of services in the stadiums, and the economic difficulties faced by spectators as the third side of the triangle, have no consequence other than the disillusionment of spectators from the Iranian Premier League stadiums. Undoubtedly, the balance between the economic status and living conditions of individuals in each society and the services fees has a positive impact on increasing spectators' attendance in stadiums. Making some national and domestic competitions open to the public, offering free or cheap transportation services, setting the ticket fees according to the economic status of the spectators, and offering incentives and discounts by the clubs in the Premier League were among the factors that can be effective in this regard.

Based on the results of the 7th mental pattern, the media plays an indelible role in the spectators' attendance in stadiums. The media rather than paying attention to the text of football is more involved in margins; it is not the right way to attract and retain fans. Since the media acts as an important agent in training spectators on various sport disciplines, it helps in increasing spectators' attendance in stadiums and contributes to the success and development of different sports. Therefore, the media can play a key role in the reconciliation between spectators and the stadiums in the Iranian Premier League by producing professional football $\mathrm{TV}$ series and useful newsletters and magazines, encouraging spectators to attend matches in stadiums, and attractively covering the text of football matches.

\section{CONCLUSION}

Spectators are the key elements in sport matches. Modern sports without spectators are neither attractive, nor viable. This issue is true about high-supported sports such as football with the presence of all strata of ages and ethnicities. Spectators are considered as the main asset of a football club; they attend football stadiums to satisfy their inner needs, and stimulate athletes and promote the development of football. Therefore, planning to persuade spectators to attend stadiums is an important task that should be put on the agenda. Considering the potential and capability of Iranian football, the presence of talents in the country, as well as the successful showing of the national team in the 2018 World Cup, the lack of spectators in football matches in Iran will undoubtedly irreparably damage the Iranian football body. The planning and implementation of the solutions presented in most of the seven mental models may lead to future success and the development of clubs and national football team in Iran.

\section{Applicable Remarks}

- Some essential measures suggested in most of the experts' mental models:

- To pay more attention to infrastructures and the construction of home stadiums.

- Pay more attention to the quality of matches as the main product of football.

- Strategic planning to attract and retain spectators and turning them into fanatic and loyal fans.

- Providing desired services in stadiums.

- Encouraging the atmosphere of stadiums free of immorality and aggression.

- Paying close attention to the livelihood of spectators and fans.

- Using media as a powerful tool to create the desired inclination.

- Influencing the attitude of spectators toward attending matches in stadiums.

\section{REFERENCES}

1. Cho H, Lee HW, Pyun DY. The influence of stadium environment on attendance intentions in spectator sport: The moderating role of team loyalty. Int J Sport Mark Spons. 2013;5(8):215-230. doi: 10.1108/IJSMS-04-2017-0025

2. Choi Y, Martin J, Park M, Yoh T. Motivational Factors Influencing Sport Spectator Involvement At NCAA Division II Basketball Games. Journal for the Study of Sports and Athletes in Education. 2013;3(3):265-284. doi: 10.1179/ssa.2009.3.3.265 
3. McCullough BP, Bergsgard NA, Collins A, Muhar A, Tyrväinen L. The Impact of Sport and Outdoor Recreation (Friluftsliv) on the Natural Environment-Background paper: The Swedish Foundation of Strategic Environmental Research (MISTRA); 2018.

4. Ayhan C, Ekinci NE, Yalçın İ, Yiğit Ş. Yiğit Ş. Investigation of constraints that occur during participation in leisure activities by high school students: A sample of Turkey. Education Sciences. Edu Sci. 2018;8(2):86. doi: 10.3390/educsci8020086

5. Gencer RT, Kiremitci O, Boyacioglu H. Spectator motives and points of attachment: an investigation on professional basketball. J Hum Kinet. 2011;30:189-196. doi: 10.2478/v10078-011-0087-9 pmid: 23487414

6. Dhurup M, Mofoka MA, Surujlal J. The relationship between stadium sportscapes dimensions, desire to stay and future attendance. Africa $J$ Physic Health Edu Recreat Dance. 2010;16(3):475-490. doi: 10.4314/ajpherd.v16i3.60925

7. Donihue MR, Findlay DW, Newberry PW. An Analysis of Attendance at Major League Baseball Spring Training Games. J Sport Econ. 2016;8(1):39-61. doi: 10.1177/1527002505276716

8. Theodorakis ND, Alexandris K, Tsigilis N, Karvounis S. Predicting spectators' behavioural intentions in professional football: The role of satisfaction and service quality. Sport Manag Rev. 2013;16(1):85-96. doi: 10.1016/j.smr.2012.05.004

9. Salgado-Barandela J, Barajas Á, Sánchez-Fernández P. nts of the spending of sporting tourists: The case of attendees at professional basketball. Europ Res Manag Bus Econ. 2018;24(3):3561675.

10. Hwang J, Lee K-W. The antecedents and consequences of golf tournament spectators' memorable brand experiences. J Destination Market Manage. 2018;9(2):1-11. doi: 10.1016/j.jdmm.2017.09.001

11. DeSchriver TD, Jensen PE. Determinants of Spectator Attendance at NCAA Division II Football Contests. $J$ Sport Manag. 2002;16(4):311-330. doi: 10.1123/jsm.16.4.311

12. Funk DC, Beaton A, Alexandris K. Sport consumer motivation: Autonomy and control orientations that regulate fan behaviours. Sport Management Review. 2012;15(3):355-367. doi: 10.1016/j.smr.2011.11.001

13. Alonso Dos Santos M, Montoro Rios FJ. Scale of spectators' motivations at soccer events. Soccer Soc. 2014;17(1):58-71. doi: 10.1080/14660970.2014.891986

14. Fink JS, Parker H, Pinson K, editors. Spectator motives: Why do we watch if our favorite team is not playing. North American Society for Sport Management Conference; 2007.

15. Caro LM, García JA. Consumer Satisfaction with a Periodic Reoccurring Sport Event and the Moderating Effect of Motivations. Sport Market Q. 2007;16(2):260-277.

16. Buraimo B. Stadium attendance and television audience demand in English league football. Managerial and Decision Economics. 2008;29(6):513-523. doi: 10.1002/mde.1421

17. Vallerand RJ, Ntoumanis N, Philippe FL, Lavigne GL, Carbonneau N, Bonneville A, et al. On passion and sports fans: A look at football. J Sport Sci. 2008;26(12):1279-1293. doi: 10.1001/jama.2016.12126 pmid: 27599330

18. Solberg HA, Turner P. Exporting sports rights to overseas markets: the case of European football. Sport Soc. 2010;13(2):354-366. doi: 10.1080/17430430903523119

19. Carvalho Md, Boen F, Sarmento JP, Scheerder J. What brings youngsters into the stadium? Sociopsychological predictors of soccer attendance among Belgian and Portuguese young fans. Revista Portuguesa de Ciências do Desporto. 2015;15(1):21-40. doi: 10.5628/rpcd.15.01.21

20. Ormesher L, Simcox LE, Tower C, Greer IA. 'To test or not to test', the arguments for and against thrombophilia testing in obstetrics. Obstet Med. 2017;10(2):61-66. doi: 10.1177/1753495X17695696 pmid: 28680464

21. Rodriguez-Pomeda J, Casani F, Alonso-Almeida MdM. Emotions' management within the Real Madrid football club business model. Soccer \& Society. 2014;18(4):431-444. doi: 10.1080/14660970.2014.980736

22. Gómez González C, García Unanue J, Sánchez Sánchez J, Ubago Guisado E, del Corral J. Evidence on soccerspecific stadiums and attendance: The Major League Soccer case. Revista de psicología del deporte. 2016;25(3):1922.

23. Glover V. Football Spectator No-Show Behavior. J Sport Econ. 2014;20(4):580-602. doi: $10.1177 / 1527002518784120$

24. Baxter R, Hastings N, Law A, Glass EJ. A rapid and robust sequence-based genotyping method for BoLADRB3 alleles in large numbers of heterozygous cattle. Anim Genet. 2008;39(5):561-563. doi: 10.1111/j.13652052.2008.01757.x pmid: 18637877

25. Brown SR. Q Technique, Method, and Methodology: Comments on Stentor Danielson's Article. Field Methods. 2009;21(3):238-241. doi: 10.1177/1525822x09332080

26. Yoshizawa G, Iwase M, Okumoto M, Tahara K, Takahashi S. Q Workshop: An Application of Q Methodology for Visualizing, Deliberating and Learning Contrasting Perspectives. Int J Environ Sci Edu. 2016;11(13):6277-6302.

27. Love A, Kavazis A, Morse A, Mayer K. Soccer-Specific Stadiums and Attendance in Major League Soccer: Investigating the Novelty Effect. J Applied Sports Manag. 2013;5(2):32-46. doi: 10.2139/ssrn.2458126 
28. Bodet G, Chanavat N. Building global football brand equity: Lessons from the Chinese market. Asia Pac $J$ Mark Logistic. 2010;22(1):55-66.

29. Neale L, Funk D. Investigating motivation, attitudinal loyalty and attendance behaviour with fans of Australian Football. Int J Sport Mark Spons. 2006;7(4):12-22. doi: 10.1108/ijsms-07-04-2006-b005

30. Zhang JJ, Smith DW, Pease DG, Mahar MT. Spectator knowledge of hockey as a significant predictor of game. Sport Mark Quar. 1996;5(3):31-48.

31. Hill B, Green BC. Repeat attendance as a function of involvement, loyalty, and the sportscape across three football contexts. Sport Manag Rev. 2000;3(2):145-162.

32. Tee DK, Preko A, Tee E. Understanding the Relationships between Service Quality, Customer Satisfaction and Loyalty: An Investigation of Ghana's Retail Banking Sector. British J Mark Stud. 2018;6(2):1-19.

33. Yoshida M, James JD. Service quality at sporting events: Is aesthetic quality a missing dimension? Sport Manag Rev. 2011;14(1):13-24. doi: 10.1016/j.smr.2009.06.002

34. Braun R, Vliegenthart R. The Contentious Fans. Int Soc. 2008;23(6):796-818. doi: $10.1177 / 0268580908095909$ 